\title{
Histopathologic Effect of Persea americana Aqueous Leaves Extract on the Liver and Kidney of Weaner Rabbits (California Species)
}

\author{
Efecto Histopatológico del Extracto Acuoso de las Hojas de Persea americana \\ sobre el Hígado y Riñón de Conejos Destetados (Especie California)
}

"Adisa, J. O.; **Ajayi, Y. \& "Egbujo, E. C.

ADISA, J. O.; AJAYI, Y. \& EGBUJO, E. C. Histopathologic effect of Persea americana aqueous leaves extract on the liver and kidney of weaner rabbits (Carlifonia Species). Int. J. Morphol., 29(4):1384-1387, 2011.

SUMMARY: Persea americana (avocado) is widely grown in parts of Southeastern Nigeria and used as a medicinal plant in the treatment of several ailments by alternative medical practitioners but very little research has been carried out on its pharmacotoxicity. This study therefore intends to study the histopathologic effect(s) of Persea americana aqueous leaf extract on the liver and kidneys of rabbits. Fresh leaves of Persea americana were processed using the Soxhlet extraction to obtain the aqueous extract. Three (3) groups of weaner rabbits namely the control, the recommended dose and the high dose groups were given water, $75 \mathrm{mg} / \mathrm{kg} / \mathrm{and} 150 \mathrm{mg} / \mathrm{kg}$ per day of the extract respectively for 28 days. The animals were sacrificed, the liver and kidney were harvested, fixed in $10 \%$ buffered formol saline, processed into paraffin wax, sectioned at $5 \mu \mathrm{m}$ and stained by the Haematoxylin and Eosin method and Perl's Prussain Blue method. Slightly better weight gain by the experimental groups suggests that the extract enhances appetite. Histopathology of the liver and kidney of the recommended and high dosage groups were not different from the control group suggesting that the plant extract is beneficial except for the observed loose stool, suggesting increased bowel emptying. This however did not affect weight gain.

KEY WORDS: Persea Americana; Liver; Kidney; Histopathology

\section{INTRODUCTION}

Persea americana (avocado) is a tree belonging to the laurel family, Lauraceae. It is indigenous to Central and South America but it is now cultivated in the United States of America, Asia, parts of Europe and Tropical Africa (Morton, 1987). Several parts of Persea americana plant have been shown to possess vasorelaxant properties and reduce vasoconstriction leading to reduction in blood pressure (Owolabi et al., 2005; Ojowole et al., 2007). In African traditional medicine, Persea americana is used in the treatment and management of variety of human ailments, including childhood convulsions and epilepsy (Ojewole \& Amabeoku, 2006). The leaves have been reported to be effective anti-tussive, antidiabetic, anti-arthritic by traditional medicine practitioner of Ibibio tribe of Southern Nigeria. Analgesic properties of the leaves have also been reported (Anita et al., 2005).

Despite the widespread use of Persea americana in the treatment of ailments (especially in non-orthodox medical

\footnotetext{
* Dept. of Med. Lab. Science, University of Jos, Nigeria.

** Government House Clinic, Ado- Ekiti, Nigeria.
}

care) the issues of appropriate dosage and harmful side effects have not been researched. Little or no literature is available on the pharmacokinetics of this plant extract and other possible biochemical, haematologic and histopathologic implications of its use. This work therefore intends to find out the histopathologic effects (if any), of the extract on the liver and kidneys and also to study the effect of iron metabolism of the liver in rabbits treated with aqueous extract of Persea americana leaf.

\section{MATERIAL AND METHOD}

Six weaned rabbits (California Species) with an average weight of $1 \mathrm{~kg}$ were used for this experiment. The rabbits were kept in the animal house of the National Veterinary Research Institute, Vom, Nigeria which had adequate ventilation, was cleaned daily and kept warm. The animals 
were allowed to acclimatize to the environment for 5days, fed with commercial feed pellets and tap water $a d$ libitum. The rabbits were assigned to 3 groups of 2 rabbits each. All animals were treated in accordance with the National Institutes of Health Guide for the Care and Use of Laboratory Animals (NCR, 1985).

Sample collection and extraction of plant material. Samples of ripe Persea americana (Avocado) were purchased from market in Jos, Nigeria. The plant material was authenticated at the Department of Botany, University of Jos, Plateau, Nigeria. The fresh leaves of Persea americana were carefully grounded using mortar and pestle and extracted using the Soxhlet extraction method (Hawthorne et al., 2000).

Experimental design. The rabbits were separated into 3 groups having two animals each (Table I). The extract was given to them by mixing it with their feed after an overnight fast. The administration of extracts to all the groups lasted for 28 days. The weight and temperature of each rabbit was measured weekly. The animals were sacrificed on the 28th day of administration and their liver and kidney harvested, fixed in $10 \%$ buffered formal saline. The organs were carefully examined for any gross abnormalities and suspicious areas selected for histopathology. The selected piece of tissues were processed into paraffin wax, sectioned at $5 \mathrm{um}$ and stained by the Haematoxylin-Eosin method to show the general tissue structures and Perl's Prussian blue method to show the pattern of iron deposit in the liver (Drury et al., 1976).

\section{RESULTS}

General observations. The fur appearance of all the rabbits before the administration of the extract was rough but in the course of the administering the extract, the fur of the control group remained rough while that of the treatment groups became smooth and glossy.

Food and water intake of the three groups was generally good and similar. At the beginning of the 4th week of administration, the fecal droppings of the treatment groups became watery.

From the graph (Fig. 1) above, the growth rate (the gradient of the graph) of each experimental group was calculated. The growth rate of the control group is 0.47 that of the recommended dose is 0.31 while that of the high dose group is 0.16 . The growth rate of the control group when compared to that of the high dose appears to be remarkably different. However, using the Analysis of Variance (ANOVA), to compare the average weight of each group, differences between the groups were not significant. This implies that the extract is not necessarily responsible for the weight changes recorded in the course of the experiment. It is however possible that the extract depresses the appetite of the rats since the rates of growth was consistently on the decline.

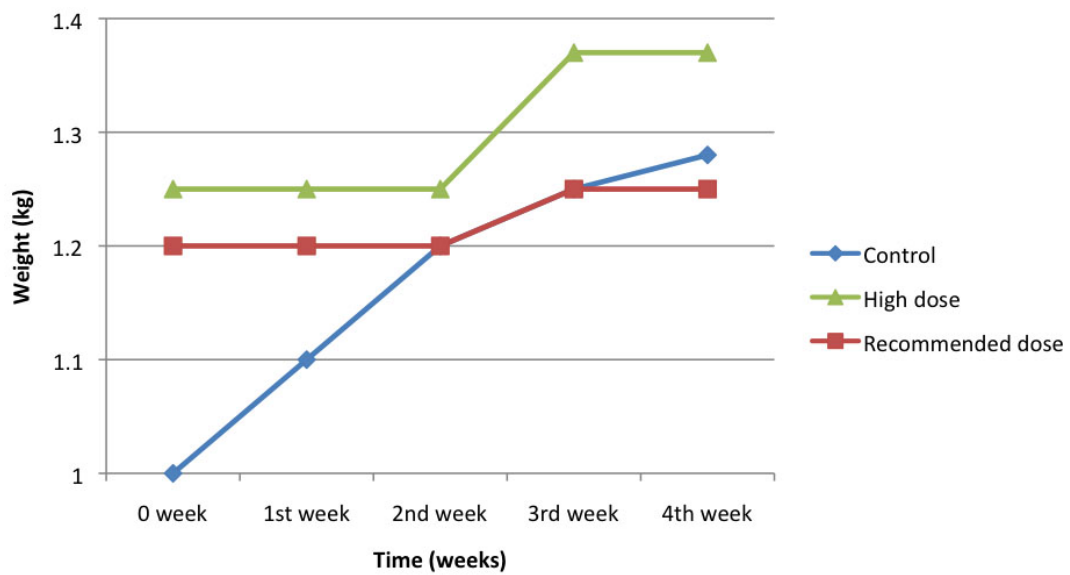

Fig. 1. Shows the mean weight changes of the experimental rabbit within the study period.

Table I. Groups of rabbits treated with the administration of extracts for 28 days.

\begin{tabular}{lcc}
\hline Group & $\begin{array}{c}\text { Treatment } \\
\text { group }\end{array}$ & $\begin{array}{c}\text { Treatment } \\
\text { Administered }\end{array}$ \\
\hline 1 & Control & Distilled water \\
2 & $*$ Recommended dose & $75 \mathrm{mg} / \mathrm{kg} / \mathrm{day}$ \\
3 & High dosage & $150 \mathrm{mg} / \mathrm{kg} /$ day \\
\hline
\end{tabular}

* The recommended dose is the estimated dose of the herb as administered by the alternative medical practitioners. 


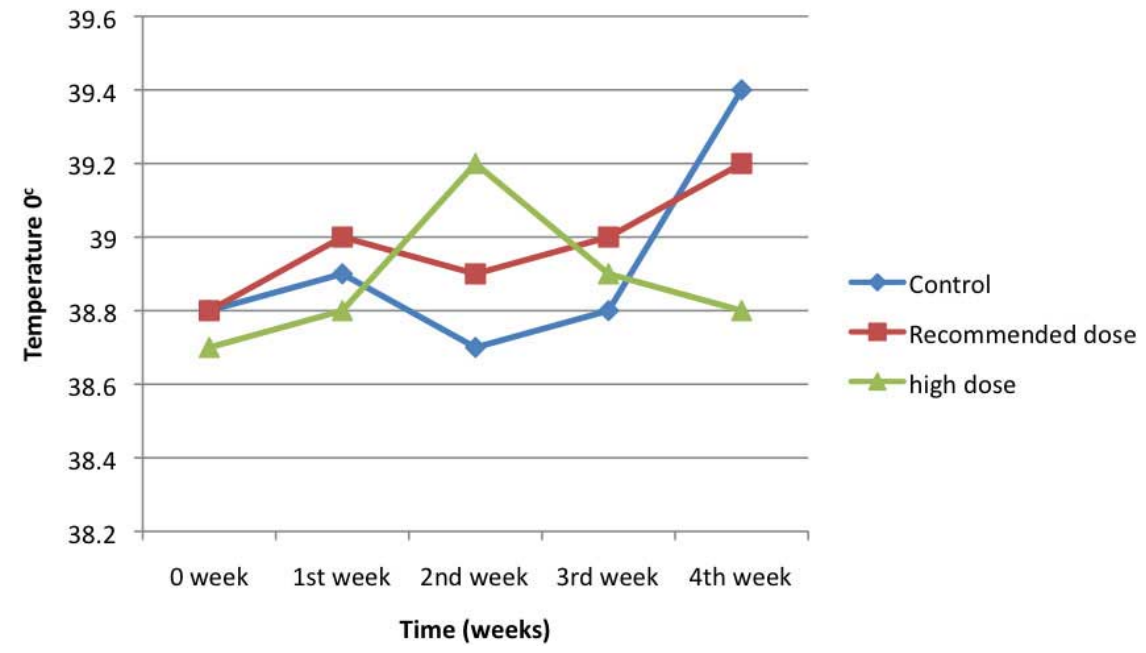

Fig. 2 shows that all the experimental groups were within the temperature range $(39.1 \pm 20$ C). Since the control is the reference, it implies that the extract did not cause any significant variation in body temperature.

Histopathological observations. Histologic sections of the liver stained using the Haematoxylin-Eosin method (H-E) of the control group as well as the treated groups did not reveal any morphologic differences or damage. The distribution of ferric iron as demonstrated by the Perl's Prussian blue reaction was also similar in both treated and control groups. This suggests that the extract, even at the dosages that were experimented upon is not damaging to its morphology and iron metabolism function

Histologic section of the kidney, also stained using the $\mathrm{H}$ and $\mathrm{E}$ method did not reveal any morphologic changes.

\section{DISCUSSION}

From the general observations, the rate of consumption of food by the treatment group was higher than that of the control group. This may be due to the hypoglycemic effect of the extract. Edem et al. (2009) and Musabayane et al. (2008) documented the hypoglycemic effect of the extract. Also, Brai et al. (2007) said that aqueous and methanolic leaf extract of Persea americana, lowers plasma glucose and influences lipid metabolism in hypercholesterolemia.

The watery stool of the treatment groups observed at the beginning of the fourth week of administration suggest that aqueous leaves extract has a relaxant effect on the gastrointestinal tract and may be related to the overall weight gain in each of the treatment groups as indicated in Figure 1. The growth rate calculated in Figure 1 shows that there was a decrease in the rate of growth with increase in the dosage of the extract. This result agrees with Brai et al., who observed that the administration of aqueous and methanolic leaf extract of Persea americana provoked a reduction in body weight gain compared to hyperlipidaemic control. It could be that Persea americana leaf extract increases the catabolism of lipids accumulated in adipose tissue resulting in a decrease in mean body weight. It is also possible that decrease in rate of growth may be due to increased bowel movement indicated by the watery stool observed in both the recommended and high dose groups.

Generally, the liver morphology was normal in both controls and treated groups except for the seemingly more noticeable granulation of the cytoplasm in the treated groups, suggesting increased metabolism. The kidney morphology was normal in both control and treated groups.

The effect of the treatment of extract on iron metabolism by the liver was examined using the Perl's Prussian blue reaction and there was an unremarkable deposition of ferric ion in the liver of both the control group and the treated groups. This suggests that the extract does not significantly affect the breakdown of red blood cells and the ability of the liver to recycle iron.

ADISA, J. O.; AJAYI, Y. \& EGBUJO, E. C. Efecto histopatológico del extracto acuoso de las hojas de Persea Americana sobre el hígado y riñón de conejos destetados (Especie California). Int. J. Morphol., 29(4):1384-1387, 2011.

RESUMEN: La Persea americana (aguacate o palta) crece ampliamente en algunas partes del sudeste de Nigeria y se utiliza como planta medicinal en el tratamiento de varias dolencias por profesionales de la medicina alternativa, pero muy poca investigación se ha llevado a cabo en relación a su toxicidad farmacológica. Este estudio tiene el objetivo de estudiar el efecto histopatológico del extracto acuoso de hojas de Persea americana sobre el hígado y riñones de conejos. Hojas frescas de Persea americana fueron procesadas mediante extracción con Soxhlet para obtener el extracto acuoso. Tres grupos de conejos destetados denominados control, dosis recomendada y dosis alta se les dio agua con $75 \mathrm{mg} /$ $\mathrm{kg} /$ día y $150 \mathrm{mg} / \mathrm{kg} /$ día del extracto res- 
pectivamente durante 28 días. Los animales fueron sacrificados. Los hígados y riñones fueron recolectados y fijados al $10 \%$ en formol tamponado y luego procesados en parafina. Se tiñeron cortes de $5 \mu \mathrm{m}$ por los métodos de Hematoxilina-Eosina y de Perl (azul de Prusia). Un aumento ligeramente mayor de peso en los grupos experimentales sugiere que el extracto aumenta el apetito de los animales. La histopatología del hígado y riñón en los grupos dosis recomendada y dosis alta no fueron diferentes al grupo control, sugiriendo que el extracto de la planta es beneficioso, excepto por el informe de heces acuosas.

PALABRAS CLAVE: Persea americana; Hígado; Riñón; Histopatología.

\section{REFERENCES}

Anita, B. S.; Okokon, J. E. \& Okon, P. A. Hypoglycemic activity of aqueous leaf extract of Persea americana Mill. Indian J. Pharmacol., 37(5):325-6, 2005.

Brai, B. I. C.; Odetola, A. A. \& Agomo, P. U. Effects of Persea americana leaf extracts on body weight and liver lipids in rats fed hyperlipidaemic diet. Afr. J. Biotechnol., 6(8):1007-11, 2007.

Drury, R. A. B.; Wallington, E. A. \& Cameron, S. R. Carleton's Histological Technique. $4^{\text {th }}$ edition. London, Oxford University Press, 1967. pp.129-31.

Edem, D.; Ekanem, I. \& Ebong, P. Effect of aqueous extracts of alligator pear seed (Persea americana mill) on blood glucose and histopathology of pancreas in alloxan-induced diabetic rats. Pak. J. Pharm. Sci., 22(3):272-6, 2009.

Hawthorne, S. B.; Grabanski, C. B.; Martin, E. \& Miller, D. J. Comparisons of soxhlet extraction, pressurized liquid extraction, supercritical fluid extraction and subcritical water extraction for environmental solids: recovery, selectivity and effects on sample matrix. J. Chromatogr. A., 892(1-2):421-33, 2000.

Musabayane, C. T.; Gondwe, M.; Kamadyaapa, D. R.; Tufts, M. A. \& Chuturgoon, A. A. Effects of Persea americana Mill (Lauraceae) ('Avocado') ethanolic leaf extract (PAE) on blood glucose and kidney function in streptozotocin (STZ)-induced diabetic rats and on kidney cell lines of the proximal (LLCPK1) and distal tubules (MDBK). Endocr. Abstr., 15:137, 2008.

Morton, J. F. Fruits of warm climates. Miami, Florida Flair Books, 1987.

National Research Council (NCR). Guide for the Care and Use of Laboratory Animals. NIH publication No. 86-23. Bethesda, National Institutes of Health, 1985.

Ojewole, J. A. \& Amabeoku, G. J. Anticonvulsant effect of Persea americana Mill (Lauraceae) (Avocado) leaf aqueous extract in mice. Phytother. Res., 20(8):696-700, 2006.
Ojewole, J. A.; Kamadyaapa, D. R.; Gondwe, M. M.; Moodley, K. \& Musabayane, C. T. Cardiovascular effects of Persea americana Mill (Lauraceae) (avocado) aqueous leaf extract in experimental animals. Cardiovasc. J. Afr., 18(2):69-76, 2007.

Owolabi, M. A.; Jaja, S. I. \& Coker, H. A. Vasorelaxant action of aqueous extract of the leaves of Persea americana on isolated thoracic rat aorta. Fitoterapia, 76(6):567-73, 2005.

\author{
Correspondence to: \\ Dr. James O. Adisa \\ Dept. of Medical Lab. Science \\ University of Jos \\ P. M. B. 2084, Jos \\ NIGERIA
}

Email: anatomyejike@yahoo.com

Received: 19-05-2011

Accepted: 18-08-2011 